\title{
Management of Sepsis in Intensive Care Units in Rajshahi Medical College, Bangladesh
}

\author{
Abu Hena Mostafa Kamal', Pranab Karmaker ${ }^{2}$, Wahida Khatun', Arup Kumar Saha ${ }^{3}$, \\ Md. Latifur Rahman4, Parvez Hassan² \\ ${ }^{1}$ ICU, Rajshahi Medical College Hospital, Rajshahi, Bangladesh \\ ${ }^{2}$ Institute of Biological Sciences, University of Rajshahi, Rajshahi, Bangladesh \\ ${ }^{3}$ City Dental College, Dhaka, Bangladesh \\ ${ }^{4}$ Islami Bank Medical College and Hospital, Rajshahi, Bangladesh \\ Email:mkamaldr@gmail.com,pranab8011@gmail.com,drwahidakhatun@yahoo.com, arupcdc@yahoo.com, \\ dr.lrapu@gmail.com, hassanprul@gmail.com
}

How to cite this paper: Kamal, A.H.M., Karmaker, P., Khatun, W., Kumar Saha, A., Rahman, Md.L. and Hassan, P. (2020) Management of Sepsis in Intensive Care Units in Rajshahi Medical College, Bangladesh. Advances in Infectious Diseases, 10, 11-25. https://doi.org/10.4236/aid.2020.101002

Received: December 28, 2019

Accepted: January 28, 2020

Published: January 31, 2020

Copyright $\odot 2020$ by author(s) and Scientific Research Publishing Inc. This work is licensed under the Creative Commons Attribution International License (CC BY 4.0).

http://creativecommons.org/licenses/by/4.0/

(c) (i) Open Access

\begin{abstract}
Background: Sepsis was a life-threatening situation affecting roughly 27 million individuals globally every year. Devoid of proper management, sepsis could develop to austere sepsis and septic shock that reason certain eight million expiries every year. Initial identification and analysis of contaminations and quick introductions of antimicrobial management had long been predictable as essential principles of treatment. Methods: All patients were evaluated thoroughly by history, clinical and laboratory findings. Serum lactate levels were collected at $0 \mathrm{hr}$ and $24 \mathrm{hrs}$ of the total admission in the ICU. Blood culture and sensitivity was performed prior to antibiotic administration in this study. Results: In this research, total sample was 1367 patients. Among these sepsis patients were 305 (nearly 22\%). These 305 studied sepsis cases, majority $128(42 \%)$ of the patients were within the age group of $41-65$ years, followed by 18 - 30 years consisting of $116(38 \%)$ and the least number of sepsis patients were in the age group of $>65$ years (20\%). This study found that 129 (42.3\%) out of 305 blood samples screened from assumed sepsis infection were affirmative for the presence of sepsis causing pathogens. Among the 129 culture positive samples, majority of the isolated micro-organisms were gram negative bacteria $58 \%$ (75), followed by gram positive bacteria $38 \%$ (49), and $3.8 \%$ (5) were the fungi Candida albicans. Conclusion: At present, mortality \& morbidity of sepsis subject was too big due to late identification, wrong $\&$ inadequate management of sepsis in the ward and also in the intensive care unit of Bangladesh.
\end{abstract}

\section{Keywords}

Sepsis, ICU, SIRS, Empirical Antibiotic 


\section{Introduction}

Sepsis was a life-threatening situation affecting roughly 27 million individuals globally every year. Devoid of suitable management, sepsis could development to austere sepsis and septic shock that might reason for the eight million expiries every year. The threat of sepsis-associated mortality raises through the age and simultaneous illnesses for example diabetes or cancer; so the occurrence of sepsis had amplified considerably, with hospitalizations and associated charges doubling over the last 10 year [1].

In entirely critically ill subjects, the instant objective was to preserve life and inhibit standby or decrease impairment to important body part for example the brain and the kidneys. Intensive care medicine was concern mainly with the organization of subjects with severe life frightening situations [2]. An ICU affords extraordinary knowledge care to the important body part and operates the expertise of medicinal, nursing and additional works for the management of the problem [3].

Allowing to that explanation an affirmative blood culture was not required for the identification of sepsis. The blood culture was affirmative in $20 \%-55 \%$ of subjects through austere sepsis [4] [5] [6] [7] and in 17\% of sepsis subjects [8]. The blood culture was affirmative in $8 \%-10 \%$ of SIRS subjects in the ER setting [9] [10]. Although one resident founded research of bloodstream contaminations in Finland cultures were affirmative in $4 \%$ of all blood cultures occupied, conforming to 28 - 44 culture affirmative bloodstream contaminations per 1000 blood cultures [11].

\section{Objectives}

\subsection{General Objective}

To develop a guideline for the management of sepsis with limited facility reducing mortality and morbidity in developing countries like Bangladesh.

\subsection{Specific Objectives}

1) To predict sepsis according to Modified SIRS criteria of SSC guideline $2012^{*}$.

2) Examining the recognition of sepsis and early signs of septic shock.

3) To predict the outcome of patients with septic shock based on serum lactate level.

4) To identify organism from cultures among the suspected case of sepsis patients admitted in the ward or intensive care unit.

\section{Materials and Methods}

\subsection{Study Population}

All subjects by assumed sepsis attend in the Emergency Observation ward, Medicine ward, Surgery ward, Neuromedicine, Gynecology, Neurosurgery and Intensive Care Unit (ICU) of Rajshahi Medical College Hospital (RMCH), Rajshahi, Bangladesh during the research period. 


\subsection{Sampling}

Random sampling considering exclusion and inclusion criteria of patients in the study.

\subsection{Inclusion Criteria}

All suspected mature subjects ( $\geq 18$ years of age) those were perceived through the life-threatening care outreach squad (or corresponding) in the ward or that were admitted to ICU throughout the research time with an identification of sepsis.

\subsection{Exclusion Criteria}

1) Chronic liver disease.

2) Poorly controlled neoplasm.

3) HIV positive cases with known end stage processes.

4) Immunosuppressant drug or transplant programmes.

5) Pregnant women.

6) Subjects on final stage of life care trail at period of identification or consultant-led judgment completed not to accelerate (prior to access through the research).

\subsection{Methodology}

History and clinical examination of the patients was performed.

- The study period was from January 2014 to December 2015.

- A total of 129 septic shock patients were taken for study.

- All these patients were evaluated thoroughly by History, Clinical and Laboratory methods.

- Serum lactate levels were collected at $0 \mathrm{hrs}$ and $24 \mathrm{hrs}$ in the ICU.

- Blood culture and antimicrobial sensitivity tests were performed before antibiotic administration.

- Serum lactate levels were categorized into:

1) Low positive (1 - $2 \mathrm{mMol} / \mathrm{L})$.

2) Moderate positive $(2-4 \mathrm{mMol} / \mathrm{L})$.

3) High positive $(>4 \mathrm{mMol} / \mathrm{l})$.

4) Normal $(<1 \mathrm{mMol} / \mathrm{l})$.

\subsection{Data Collection}

All demographic, experimental and research laboratory data were documented in a pre-designed records collection sheet.

\subsection{Procedure}

It was controlled to total subjects offering towards the zone at the hospital who saw the explanation of sepsis. For these subjects, entrance to the intensive care unit was measured at the decision of the doctor in duty. Subjects through austere 
sepsis, containing of the incidence of two SIRS displays and above one or more signs of "sepsis-associated" organ dysfunction were admitted to the intensive care unit. Total subjects in septic shock-showing through the two sepsis signs and hypotension insensitive to suitable unsolidified revival were acknowledged to the ICU.

\subsection{Ethical Approval}

The research procedure was permitted by the official examination board of Rajshahi Medical College, Rajshahi. Informed written consent was obtained from each patient attendant after briefing about the research. Documents were taken in a permitted records collection form.

\subsection{Statistical Analysis}

Entire documents were studied by means of computer founded SPSS (statistical program for social science) program version 11.0 for Windows. $\mathrm{P}$ value of less than 0.05 was taken statistically significant.

\section{Results and Observations}

\subsection{Subjects of the Present Study (Total Patients)}

All patients with suspected sepsis attending the Emergency Observation ward, Medicine ward, Surgery ward, Neuromedicine, Gynecology, Neurosurgery and ICU of Rajshahi Medical College Hospital (RMCH), Rajshahi, a tertiary level government hospital situated in the Northern region of Bangladesh throughout the study period of January 2014 to December 2015 were included in the study. As shown in Figure 1. The entire sum of subjects admitted to the ICU of Rajshahi Medical College Hospital (RMCH), Rajshahi, Bangladesh throughout the research period was 1367, out of them 1026 patients were diagnosed as non-sepsis patients founded on medical inspection and research laboratory outcomes. The numbers of sepsis patients diagnosed were found to be 305 (22\%) founded on medical inspection and research laboratory outcomes.

The most common source of patient admission to the ICU was from the Medicine ward 190 (62.3\%), followed by surgery or surgical ward 96 (31.5\%) and the least numbers of patients $19(6.2 \%)$ were from the post-operative wards (Table 1 and Figure 2). The above result was found to be statistically as the calculated p-value was $<0.00001$ and significant at $\mathrm{p}<0.05$. Most of the suspected

Table 1. Patient admission to ICU from different wards.

\begin{tabular}{cccccc}
\hline & & Frequency & Percent & Valid Percent & Cumulative Percent \\
\hline \multirow{4}{*}{ Valid } & Surgical ward & 96 & 31.5 & 31.5 & 31.5 \\
& Medicine ward & 190 & 62.3 & 62.3 & 93.8 \\
& Postoperative & 19 & 6.2 & 6.2 & 100.0 \\
& Total & 305 & 100.0 & 100.0 & \\
\hline
\end{tabular}




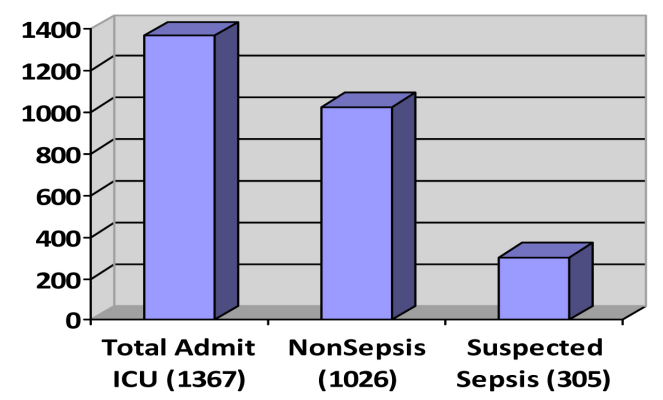

Figure 1. Total patients of the present study.

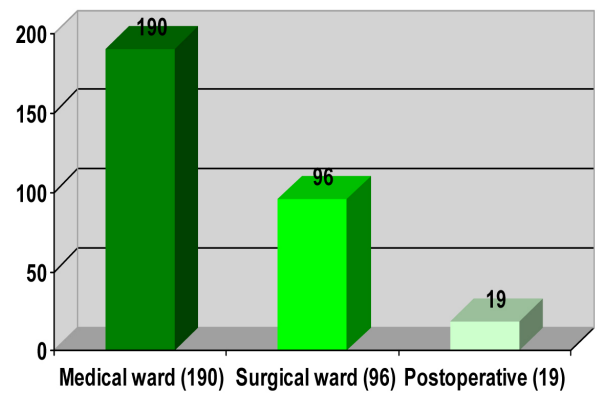

\begin{tabular}{|c|c|}
\hline \multicolumn{2}{|c|}{ Test Statistics } \\
\hline & Source of Admission. \\
\hline Chi-Square & $144.282^{\mathrm{a}}$ \\
\hline $\mathrm{df}$ & 2 \\
\hline Asymp. Sig. & .0001 \\
\hline
\end{tabular}

Figure 2. Ward wise source of patient admission to the ICU.

sepsis subjects admitted to the ICU of RMCH had acute lung injury and accounted for 244 sepsis patients which are $80 \%$ of the total sepsis patients of the study. The result was found to be statistically significant as the calculated $\mathrm{p}$ value was $<0.00001$ and significant at $\mathrm{p}<0.05$.

\subsection{Oxygen Saturation of the Patients}

Equally the intemperance of hypoxaemia and hyperoxia had the possible to damage critically hostile subjects and deteriorate their results. Oxygen capacities restrained with pulse oximetry $\left(\mathrm{SpO}_{2}\right)$ were the favored means of observing oxygenation in maximum situations and were used globally in critical care. Under the present study, Oxygen saturations was continuously monitored for all 305 sepsis patients admitted in the ICU and the results have been presented in Table 2 and Figure 3. Majority of the ICU admitted patients i.e. 285 (nearly 95\%) were hypoxic; $\mathrm{O}_{2}$ saturation was below $95 \%$. From test statistics the calculated $\mathrm{p}$-value was $<0.0001$ and the outcome was significant at $\mathrm{p}<0.05$.

In the present study, out of 305 sepsis patients admitted during the study period majority 275 (90\%) had developed tachypnea ( $>25$ breaths/min). From the test statistics $\mathrm{p}$-value was $<0.001$ and the outcome was statistically significant at $\mathrm{p}<0.05$.

\subsection{Serum Lactate Level ( 0 hrs)}

The serum lactate levels upon admission of the patient to the ICU have been presented in Table 3 and Figure 4 and Figure 5. On admission, serum lactate level were moderately high/positive (>2.1 mmol/L) among 200 (66\%) patients, 
Table 2. Oxygen saturation of the ICU admitted patients $(n=305)$.

\begin{tabular}{cccccc}
\hline & & Frequency & Percent & Valid Percent & Cumulative Percent \\
\hline \multirow{4}{*}{ Valid } & $<95 \%$ & 285 & 94.4 & 94.4 & 94.4 \\
& 95 & 8 & 2.6 & 2.6 & 96.1 \\
& $>95 \%$ & 12 & 3.9 & 3.9 & 100.0 \\
& Total & 305 & 100.0 & 100.0 & \\
\hline
\end{tabular}

Table 3. Serum lactate level at admission of the patient to the ICU.

\begin{tabular}{cccccc}
\hline & & Frequency & Percent & Valid Percent & Cumulative Percent \\
\hline & Normal $(<1 \mathrm{mmol} / \mathrm{L})$ & 19 & 6.2 & 6.2 & 6.2 \\
Low positive $(1-2 \mathrm{mmol} / \mathrm{L})$ & 81 & 26.6 & 26.6 & 32.8 \\
Valid & $\begin{array}{c}\text { Moderate positive } \\
(2.1-4 \mathrm{mmol} / \mathrm{L})\end{array}$ & 200 & 65.6 & 65.6 & 98.4 \\
& High positive $(>4 \mathrm{mmol} / \mathrm{L})$ & 5 & 1.6 & 1.6 & 100.0 \\
& Total & 305 & 100.0 & 100.0 & \\
\hline
\end{tabular}

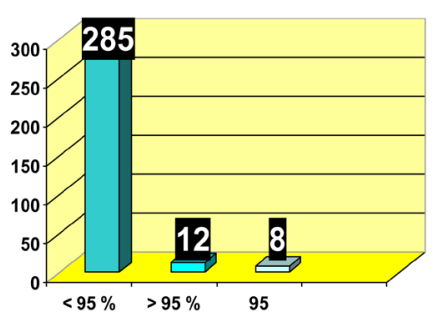

Test Statistics

\begin{tabular}{|c|c|}
\hline & Oxygen Saturation Group of patient \\
\hline Chi-Square & $495.980^{\mathrm{a}}$ \\
\hline $\mathrm{df}$ & 2 \\
\hline Asymp. Sig. & 0.0001 \\
\hline
\end{tabular}

Figure 3. Oxygen saturation of the ICU admitted patients.

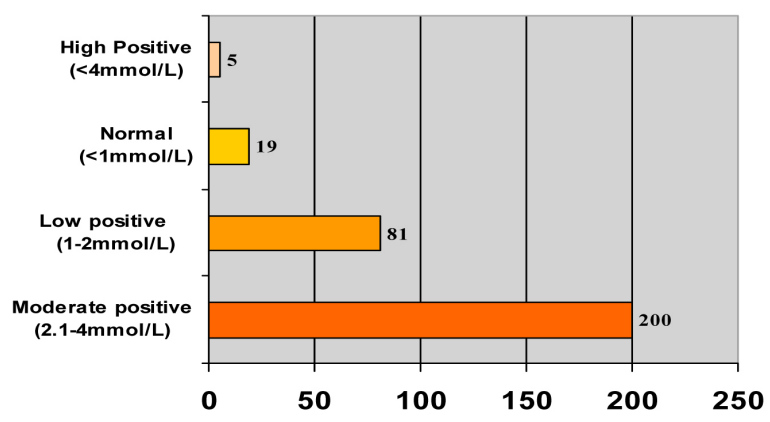

Figure 4. Serum lactate levels at admission to the ICU.

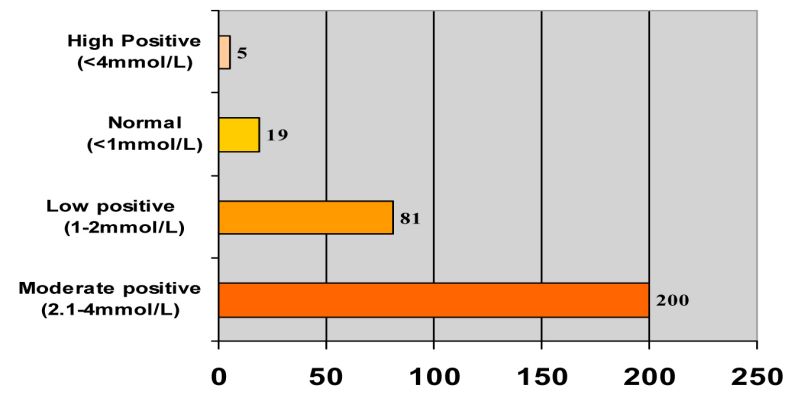

Figure 5. Serum lactate levels at admission (Cross tab). 
out of the total 305 sepsis patients admitted in ICU throughout the research period.

On admission, serum lactate level are moderately positive $200(66 \%)$ out of 305 patient

\subsection{Serum Lactate Level after 24 hrs Admission to ICU}

Figure 6 shows the serum lactate level of the sepsis patients under the present study after $24 \mathrm{hrs}$ treatment in the ICU of RMCH. It is clear from the figure that after $24 \mathrm{hrs}$ treatment, number of moderate serum lactate positive patients reduced from 200 to 128 , but number of high serum lactate positive patients increased from 05 to 61 and improved number of patients low positive from 81 to 103.

\subsection{Fast Fluid Administrations}

Fluid management was the first-line intercession to reinstate the systemic hemodynamics and upsurge oxygen distribution to match oxygen request in septic subjects.

Figure 7 shows the fluid administration data on the patients $(n=305)$ admitted in the ICU of RMCH during the present study has been presented. The fast fluid administration was required in majority 258 (nearly 85\%) of the subjects admitted to ICU when hypotension (Mean Arterial Pressure, MAP $<65 \mathrm{~mm}$ ) was noticed. From the test statistics the calculated p-value was $<0.00001$ and the

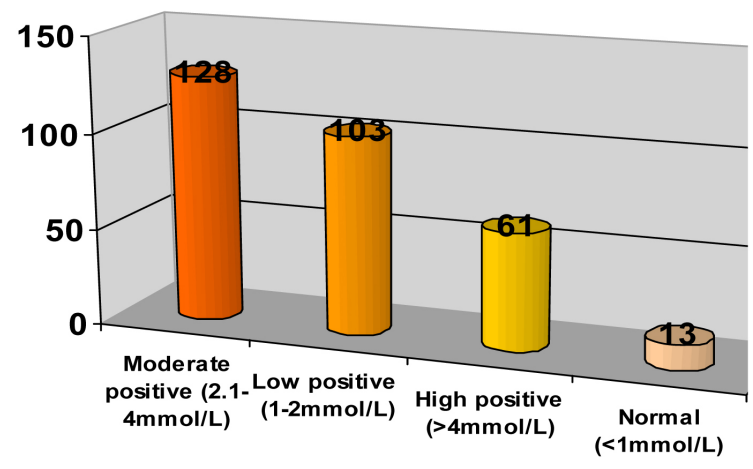

Figure 6. Serum lactate level after $24 \mathrm{hrs}$ admission to ICU.

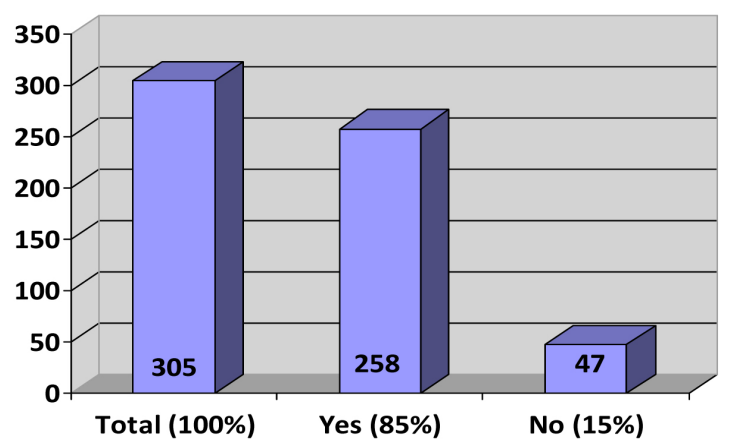

Figure 7. Fluid administration data on the patients. 
outcome was significant at $\mathrm{p}<0.05$. $\mathrm{P}$-value was calculated from chi-square calculator (online) p-value from chi-square calculator (online).

http://www.socscistatistics.com/p-values

\subsection{Findings of Blood Culture of the Patients}

Blood culture remains the gold standard of identification to isolate the etiologic agents (micro-organisms) for sepsis. This study found that 129 (42.3\%) out of 305 total blood samples screened from suspected sepsis cases were positive for the presence of bacteria as shown in Figure 8.

Among the 129 culture positive samples, majority of the isolated micro-organisms were gram negative bacteria 58\% (75) followed by gram positive bacteria $38 \%$ (49) and 3.8\% (5) were the fungi Candida albicans. The distribution of isolated pathogens of sepsis has been presented in Table 4. From the data it is clearly evident that the most frequent bacteria in the ICU of RMCH are the Grampositive bacterium Coagulase-negative staphylococcus (CONS) 30 (23.4\%) and the gram-negative bacterium Klebsiella pneumoniae 29 (22.5\%).

\subsection{Antimicrobial Sensitivity Pattern of the Bacteria Isolated from Sepsis Patients}

The antimicrobial susceptibility testing of the isolated bacteria from sepsis patients admitted to the ICU was performed by the modified Bauer Kirby disc diffusion technique (Culture sensitivity) on Mueller Hinton agar against nine (09) antibiotics and the sensitivity presented in Table 5. The etiological pathogens of sepsis isolated from the ICU of Rajshahi medical college hospital, Rajshahi, were found to be most sensitive to the antibiotic meropenem (75.19\%), followed by gentamicin $11(8.42 \%)$.

\subsection{Antimicrobial Resistance Pattern of the Bacteria Isolated from Sepsis Patients}

The antimicrobial resistance testing of the isolated bacteria from sepsis patients admitted to the ICU was performed by the modified Bauer Kirby disc diffusion technique (Culture sensitivity) on Mueller Hinton agar against nine (09) antibiotics. The etiological pathogens of sepsis isolated from the ICU of Rajshahi

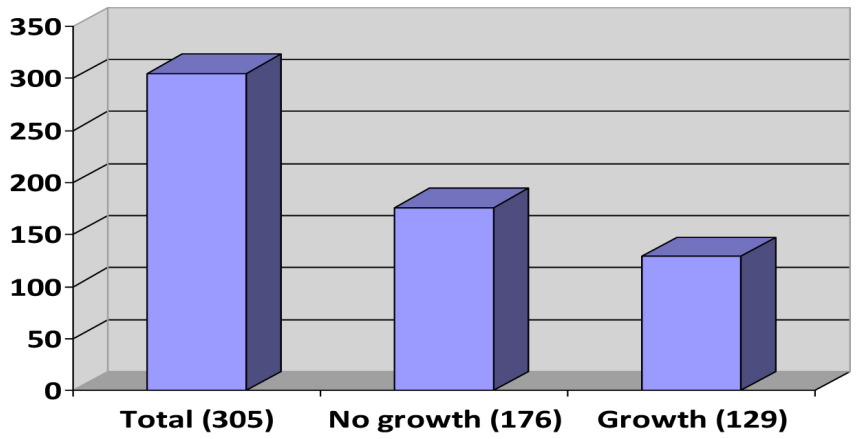

Figure 8. Results of blood culture from sepsis patients. 
Table 4. Micro-organisms isolated from the blood sample of sepsis subjects by culture.

\begin{tabular}{ccc}
\hline Micro-organisms & Frequency & Percent \\
\hline Gram positive & & \\
Coagulase-negative staphylococci (CoNS) & 30 & 23.4 \\
Staphylococus aureus (MRSA) & & \\
Enterococcus faecallis & 16 & 12.3 \\
Total gram positive & 3 & 2.3 \\
Gram negative & 49 & $38 \%$ \\
Klebsiella pneumoniae & 29 & 22.5 \\
Escherichia coli & & \\
Valid & 25 & 19.5 \\
Acinetobacter spp. & 13 & 10.1 \\
Pseudomonas spp. & 8 & 6.1 \\
Total gram negative & 75 & $58 \%$ \\
Candida albicans & 5 & $3.8 \%$ \\
Grand Total & 129 & 100 \\
\hline
\end{tabular}

Table 5. Antimicrobial sensitivity of isolated bacteria from sepsis patients.

\begin{tabular}{cccc}
\hline & Frequency & Percent \\
\hline Ceftriaxone & 2 & 1.55 \\
Ciprofloxacin & 5 & 3.88 \\
Azythromycin & 6 & 4.65 \\
Meropenem & 97 & 75.19 \\
& Teicoplanin & 3 & 2.32 \\
& Vancomycin & 2 & 1.55 \\
& Imipenum & 1 & 0.77 \\
Amikacin & 2 & 1.55 \\
Gentamicin & 11 & 8.52 \\
\hline
\end{tabular}

medical college hospital, Rajshahi, Bangladesh, were found to be resistant $21 \%$ (94) to the widely used injectable antibiotic ceftriaxone.

\subsection{Empirical Antibiotic Therapy}

Table 6 shows the frequency of the type of empiric antibiotics used for the study patients. Ceftriaxone were selected most frequently $(61 \%)$ for the control of unknown sepsis, followed by Meropenam/Teicoplanin (13.8\%) for treating Hospital acquired chest infection with VAP, Co-moxiclav/Piperacillin + tazobactum (8.5\%) for aspiration pneumonia reflecting the guideline oriented selection of antibiotics by the attending doctors. The above findings were found to be statistically significant as evidenced from the test statistics were the calculated p-value was $<0.00001$ and the result is significant at $\mathrm{p}<0.05$. 
Table 6. Frequency of the type of empiric antibiotics used for the study patients.

\begin{tabular}{ccccc}
\hline Antibiotics used & Frequency & Percent & Valid Percent & Cumulative Percent \\
\hline Unknown Sepsis-Ceftriaxone & 186 & 61.0 & 61.0 & 61.0 \\
Line related-Teicoplanin + Meropenam & 1 & 0.3 & 0.3 & 61.3 \\
C.A.Pneumonia-Moxifloxacin + Azithromycin. & 18 & 5.9 & 5.9 & 67.2 \\
Intra-abdominal source-Imipenam + Metronidazole & 18 & 5.9 & 5.9 & 73.1 \\
Female genital tract-Ceftriaxone + Mertonidaxole + Azithromycin & 3 & 1.0 & 1.0 & 74.1 \\
Aspiration Pneumonia-Co-amoxiclav/(Piperacillin + taxobactum) & 26 & 8.5 & 8.5 & 82.6 \\
Hosp. acq. chest infection with VAP-Meropenam/Teicoplanin & 42 & 13.8 & 13.8 & 96.4 \\
Unknown S.Shock-meropenam + Vancomycin/Teicoplanin & 11 & 3.6 & 3.6 & 100.0 \\
Total & 305 & 100.0 & 100.0 &
\end{tabular}

\subsection{Year Wise Sepsis Disposition (Death and Survival) in the ICU of RMCH (2014 and 2015)}

In the present study directed since January 2014 to December 2015, the entire amount of sepsis patients in the ICU of RMCH, Rajshahi, Bangladesh were 305 (22\%) based on scientific examination and laboratory outcomes. The patient survival and death rates from sepsis i.e. the sepsis disposition in the ICU of RMCH during the year 2014 has been presented in Figure 9. In 2014, total 106 sepsis patients were treated in the ICU and among them 58 patients survived and left the ICU while 48 patients died. Therefore, the mortality rate was $45.28 \%$ and survival rate was $54.71 \%$ in the year 2014 .

Again, in the year 2015, total 199 sepsis patients were treated in the ICU and among them 124 patients survived and left the ICUs while 75 patients died (Figure 10). The mortality rate was therefore, $37.68 \%$ and survival rate was $62.31 \%$ in the year 2015 .

\subsection{Total Sepsis Disposition of the Current Study}

Figure 11 shows the total sepsis disposition (death and survival statistics) of the current study leads since January 2014 to December 2015. Entire numbers of sepsis patients admitted in the ICU of RMCH, rajshahi, Bangladesh were 305. Out them 162 (53.1\%) patients survived and were released from ICUs, on the other hand, 143 (46.9\%) patients expired.

\section{Discussion}

This research defines the scientific management outcomes of subjects in rajshahi medical college hospital, Bangladesh with severe sepsis needing admission to the ICU, providing indigenous and universal healthcare specialists a richer interpretation of the condition in the area. Organization of austere sepsis includes diagnosis, original revival, antibiotic treatment, source regulator, fluid treatment, vasopressors, corticosteroids, blood product organization, glucose regulator, bicarbonate treatment. 


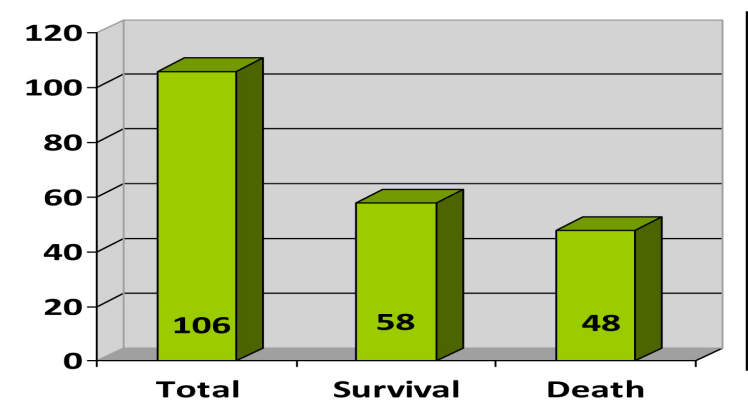

\begin{tabular}{|c|c|c|c|c|c||}
\hline \multicolumn{7}{|c|}{ ANOVA 2014 } \\
\hline $\begin{array}{c}\text { Patient } \\
\text { ID }\end{array}$ & $\begin{array}{c}\text { Sum of } \\
\text { Squares }\end{array}$ & df & $\begin{array}{c}\text { Mean } \\
\text { Square }\end{array}$ & F & Sig. \\
\hline $\begin{array}{c}\text { Between } \\
\text { Groups }\end{array}$ & 3473.868 & 1 & 3473.868 & 3.471 & 0.065 \\
\hline $\begin{array}{c}\text { Within } \\
\text { Groups }\end{array}$ & 104096.858 & 104 & 1000.931 & & \\
\hline Total & 107570.726 & 105 & & & \\
\hline \multicolumn{7}{|l|}{} \\
\hline
\end{tabular}

Figure 9. Sepsis disposition (death and survival) in ICU of RMCH in 2014.

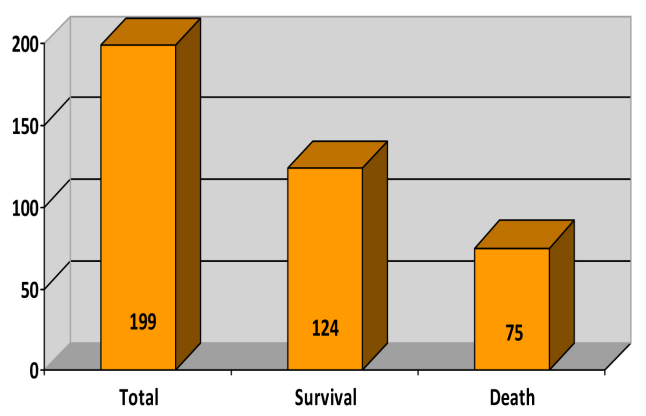

\begin{tabular}{|c|c|c|c|c|c|}
\hline \multicolumn{7}{|c|}{ ANOVA 2015 } \\
\hline $\begin{array}{c}\text { Patient } \\
\text { ID }\end{array}$ & $\begin{array}{c}\text { Sum of } \\
\text { Squares }\end{array}$ & df & $\begin{array}{c}\text { Mean } \\
\text { Square }\end{array}$ & F & Sig. \\
\hline $\begin{array}{c}\text { Between } \\
\text { Groups }\end{array}$ & 507.405 & 1 & 507.405 & 0.124 & 0.725 \\
\hline $\begin{array}{c}\text { Within } \\
\text { Groups }\end{array}$ & 805752.896 & 197 & $\begin{array}{c}4090.11 \\
6\end{array}$ & & \\
\hline Total & 806206.302 & 198 & & & \\
\hline
\end{tabular}

Figure 10. Sepsis disposition (death and survival) in ICU of RMCH in 2015.

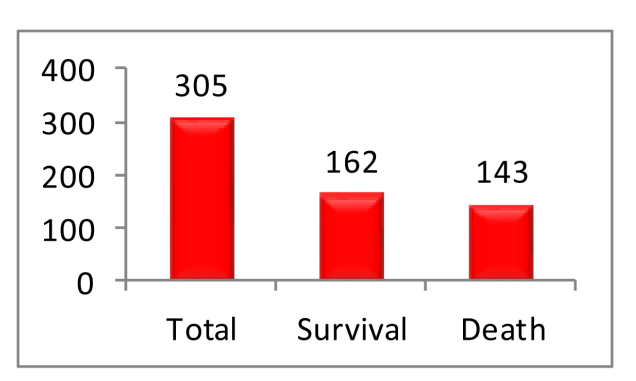

\begin{tabular}{|c|c|c|c|c|c|}
\hline \multicolumn{7}{|c|}{ ANOVA 2015 } \\
\hline $\begin{array}{c}\text { Patient } \\
\text { ID }\end{array}$ & $\begin{array}{c}\text { Sum of } \\
\text { Squares }\end{array}$ & df & $\begin{array}{c}\text { Mean } \\
\text { Square }\end{array}$ & F & Sig. \\
\hline $\begin{array}{c}\text { Between } \\
\text { Groups }\end{array}$ & 6139.718 & 1 & 6139.718 & 0.781 & 0.378 \\
\hline $\begin{array}{c}\text { Within } \\
\text { Groups }\end{array}$ & 2381823.154 & 197 & 7860.802 & & \\
\hline Total & 2387962.872 & 198 & & & \\
\hline
\end{tabular}

Figure 11. The total sepsis disposition (death and survival statistics).

Protocolized, numerical recovery of subjects through sepsis tempted tissue hypoperfusion (distinct in this text as hypotension persevering later early fluid test or blood lactate concentration $\geq 4 \mathrm{mmol} / \mathrm{l}$ ).

\subsection{Aims through the First 6 hrs of Recovery}

1) CVP 8 - $12 \mathrm{mmHg}$.

2) $\mathrm{MAP} \geq 65 \mathrm{~mm} \mathrm{Hg}$.

3) Urine output $\geq 0.5 \mathrm{~mL} / \mathrm{kg} / \mathrm{hr}$.

4) $\mathrm{ScvO}_{2} 70 \%$ or $65 \%$, respectively (grade $1 \mathrm{C}$ ).

In subjects with raised lactate aim was to regularize it (Grade 2C).

\subsection{Antimicrobial Treatment}

Administration of effective intravenous antimicrobials inside the $1^{\text {st }}$ hour of identification of septic shock (grade 1B) and austere sepsis devoid of septic shock 
(grade 1C) so the aim of treatment were combination empirical treatment for neutropenic subjects through austere sepsis (grade 2B) and for subjects by means of tough to treat, multidrug-resistant microbial pathogens for example Acinetobacter and Pseudomonas spp. (grade 2B). On behalf of subjects through austere contaminations related with breathing failure and septic shock, mixture of treatment through an extended spectrum beta-lactam and either an aminoglycoside or a fluoroquinolone was for $P$. aeruginosa bacteremia (grade 2B). A mixture of beta-lactam and macrolide for subjects with septic shock from bacteremic Streptococcus pneumoniae contaminations (grade 2B).

Empiric arrangement treatment would not be managed for more than 3 - 5 days. De-escalation to the maximum suitable particular treatment would be accomplished as early as the vulnerability outline was known (grade 2B). Period of treatment usually 7 - 10 days; extended sequences might be suitable in subjects who had a sluggish medical reply, undrainable foci of contamination, bacteremia through $S$. aureus, certain mycological and virus-related contaminations or immunologic insufficiencies, containing neutropenia (grade 2C). Anti-virus related treatment started as soon as probable in subjects with austere sepsis or septic shock of viral origin (grade 2C).

\subsection{Fluid Therapy}

Crystalloids as the early fluid of selected in the recovery of austere sepsis and septic shock (grade 1B). In contradiction of the usage of hydroxyethyl starches for fluid recovery of austere sepsis and septic shock (grade 1B). Initial fluid challenge in subjects through sepsis persuaded tissue hypoperfusion through misgiving of hypovolemia to accomplish at least of $30 \mathrm{ml} / \mathrm{kg}$ of crystalloids (grade 1C).

Albumin in the fluid recovery of austere sepsis and septic shock once subjects oblige considerable quantities of crystalloids (grade 2C). Fluid challenge method be applied wherein fluid administration was sustained as soon as there was hemodynamic development whichever founded on dynamic (e.g., change in pulse pressure, stroke volume variation) or stagnant variables (e.g., arterial pressure, heart rate).

\subsection{Vasopressors}

Vasopressor treatment originally aim to a MAP of $65 \mathrm{mmHg}$ (grade 1C). Norepinephrine as the major choice vasopressor (grade 1B). Epinephrine (added to and potentially replaced for norepinephrine) as soon as an extra mediator was wanted to preserve satisfactory blood pressure (grade 2B). Vasopressin 0.03 units/minute could be additional to norepinephrine through determined of each levitation MAP or declining norepinephrine dosage. Dopamine as an substitute vasopressor mediator to norepinephrine only in extremely nominated subjects (e.g., subjects with little threat of tachyarrhythmia's and complete or comparative bradycardia) (grade 2C). An experimental of dobutamine brew up to 20 
$\mathrm{mcg} / \mathrm{kg} / \mathrm{min}$ be administered or added to vasopressor in the attendance of

1) myocardial dysfunction as recommended through raised cardiac substantial pressures and low cardiac output, or

2) Ongoing signs of hypoperfusion, in spite of attaining satisfactory intravascular capacity and satisfactory MAP (grade 1C).

\subsection{Corticosteroids}

Not spending intravenous hydrocortisone to treat mature septic shock subjects if acceptable fluid recovery and vasopressor treatment were talented to reinstate hemodynamic constancy.

In this situation it was not attainable; we recommend intravenous hydrocortisone unaccompanied at a dose of $200 \mathrm{mg}$ per day (grade 2C). When hydrocortisone was specified, use incessant flow (grade 2D).

\subsection{Blood Product Administration}

As soon as tissue hypoperfusion had fixed and in the deficiency of mitigating situations, for example myocardial ischemia, severe hypoxemia, acute hemorrhage, or ischemic heart disease, then advised that RBC transfusion arise merely as soon as hemoglobin $<7.0 \mathrm{~g} / \mathrm{dl}$ to aim a hemoglobin of $7.0-9.0 \mathrm{~g} / \mathrm{dl}$ in grown-ups (grade 1B). In subjects with acute sepsis, manage platelets prophylactically when counts were $<10,000 / \mathrm{mm}^{3}$ in the nonappearance of obvious hemorrhage. We advised prophylactic platelet transfusion when counts were < $20,000 / \mathrm{mm}^{3}$ if the subject had a substantial danger of hemorrhage. Higher platelet counts $\left(\geq 50,000 / \mathrm{mm}^{3}\right)$ were suggested for vigorous hemorrhage, operation, or aggressive techniques (grade $2 \mathrm{D}$ )

\subsection{Control of Glucose}

A procedure method to blood glucose supervision in ICU subjects with austere sepsis starting insulin treating once 2 successive blood glucose stages were $>180$ $\mathrm{mg} / \mathrm{dl}$. This procedure method would aim a higher blood glucose $\leq 180 \mathrm{mg} / \mathrm{dl}$ rather than a higher target blood glucose $\leq 110 \mathrm{mg} / \mathrm{dL}$ (grade 1A).

\subsection{Bicarbonate Therapy}

Not using sodium bicarbonate therapy for the purpose of improving hemodynamics or reducing vasopressor requirements in patients with hypoperfusioninduced lactic acidemia with $\mathrm{pH} \geq 7.15$ (grade 2B).

\section{Prevention}

If there is an infection, we can prevent it from turning to sepsis by treating seriously.

This means:

WHO 5 moments hand hygiene maintaining by HCW.

Taking antibiotic as recommended.

Concluding the whole course of antibiotic. 
Don't consume antibiotic unnecessarily, That will help to decrease the probabilities of increasing antibiotic-resistant contaminations.

Don't consume someone else's antibiotic.

\section{Source control}

A precise functional identification of contamination requiring consideration for developing source regulator to be required and diagnosed or omitted as soon as possible, and interference be accepted for source control within the first $12 \mathrm{hr}$ after the diagnosis was made, if possible (grade 1C).

\section{The World Sepsis Declaration}

"Sepsis is one of the most common, least-recognized illnesses in both the developed and developing world."

In Rajshahi Medical College Hospital, Bangladesh, it is low resource setting ICU \& some lab. Test, drugs and equipment not available in Rajshahi City, Banglaesh.

\section{So, My Recommendation}

1) Diagnosis - Fever + Alteration of W.B.C \& or $\uparrow$ Neutrophil.

2) Management - start $<01$ hrs.

a) Initiation of Blood Culture.

b) Empirical Broad Spectrum Antibiotics starts, If Age $>65$ yrs, \&/or DM, don't use Inj. Ceftriaxone.

c) Blood lactate level on Admission \& after 24 hrs.

d) If Serum lactate level high \&/or Hypotension (MAP $<65 \mathrm{~mm} \mathrm{hg}$ ), start 15 $20 \mathrm{ml} / \mathrm{KG} \mathrm{0.9 \%}$ Normal Saline.

e) If Hypotension persist, Start Inj. Inotropes (Inj. Dobutamine/Inj. Vasopres$\sin )$.

The scenario of Infectious diseases and the changes that come with it are such that every year is a fresh challenge and a dynamic one. What was certainly working two years ago is a possible likelihood now and may well undergo a sea change in the foreseeable future!

\section{Conflicts of Interest}

The author declares no conflicts of interest regarding the publication of this paper.

\section{References}

[1] Bone, R.C., Sibbald, W.J. and Sprung, C.L. (1992) The ACCP-SCCM Consensus Conference on Sepsis and Organ Failure. Chest, 101, 1481-1483.

https://doi.org/10.1378/chest.101.6.1481

[2] Rangel-Frausto, M.S., Pittet, D., Costigan, M., Hwang, T., Davis, C.S. and Wenzel, R.P. (1995) The Natural History of the Systemic Inflammatory Response Syndrome (SIRS). A Prospective Study. JAMA, 273, 117-123. https://doi.org/10.1001/jama.273.2.117

[3] Le Gall, J.R., Lemeshow, S., Leleu, G., Klar, J., Huillard, J., Rué, M., Teres, D. and Artigas, A. (1995) Customized Probability Models for Early Severe Sepsis in Adult 
Intensive Care Patients. Intensive Care Unit Scoring Group. JAMA, 273, 644-650. https://doi.org/10.1001/jama.273.8.644

[4] Alberti, C., Brun-Buisson, C., Burchardi, H., Martin, C., Goodman, S., Artigas, A., Sicignano, A., Palazzo, M., Moreno, R., Boulme, R., Lepage, E. and Le Gall, R. (2002) Epidemiology of Sepsis and Infection in ICU Patients from an International Multicentre Cohort Study. Intensive Care Medicine, 28, 108-121. https://doi.org/10.1007/s00134-001-1143-Z

[5] Valles, J., Rello, J., Ochagavia, A., Garnacho, J. and Alcala, M.A. (2003) Community Acquired Bloodstream Infection in Critically Ill Adult Patients: Impact of Shock and Inappropriate Antibiotic Therapy on Survival. Chest, 123, 1615-1624. https://doi.org/10.1378/chest.123.5.1615

[6] Ylipalosaari, P., Ala-Kokko, T.I., Laurila, J., Ohtonen, P. and Syrjälä, H. (2006) Epidemiology of Intensive Care Unit (ICU)-Acquired Infections in a 14-Month Prospective Cohort Study in a Single Mixed Scandinavian University Hospital ICU. Acta Anaesthesiologica Scandinavica, 50, 1192-1197. https://doi.org/10.1111/j.1399-6576.2006.01135.x

[7] Karlsson, S., Varpula, M., Ruokonen, E., Pettilä, V., Parviainen, I., Ala-Kokko, T.I., Kolho, E. and Rintala, E.M. (2007) Incidence, Treatment, and Outcome of Severe Sepsis in ICU-Treated Adults in Finland: The Finnsepsis Study. Intensive Care Medicine, 33, 435-443. https://doi.org/10.1007/s00134-006-0504-z

[8] Brun-Buisson, C., Doyon, F. and Carlet, J. (1996) Bacteremia and Severe Sepsis in Adults: A Multicenter Prospective Survey in ICUs and Wards of 24 Hospitals. French Bacteremia-Sepsis Study Group. American Journal of Respiratory and Critical Care Medicine, 154, 617-624. https://doi.org/10.1164/ajrccm.154.3.8810595

[9] Bates, D.W., Sands, K., Miller, E., Lanken, P.N., Hibberd, P.L., Graman, P.S., Schwartz, J.S., Kahn, K., Snydman, D.R., Parsonnet, J., Moore, R., Black, E., Johnson, B.L., Jha, A. and Platt R. (1997) Predicting Bacteremia in Patients with Sepsis Syndrome. Academic Medical Center Consortium Sepsis Project Working Group. The Journal of Infectious Diseases, 176, 1538-1551. https://doi.org/10.1086/514153

[10] Yanagihara, K., Kitagawa, Y., Tomonaga, M., Tsukasaki, K., Kohno, S., Seki, M., Sugimoto, H., Shimazu, T., Tasaki, O., Matsushima, A., Ikeda, Y., Okamoto, S., Aikawa, N., Hori, S., Obara, H., Ishizaka, A., Hasegawa, N., Takeda, J., Kamihira, S., Sugahara, K., Asari, S., Murata, M., Kobayashi, Y., Ginba, H., Sumiyama, Y. and Kitajima, M. (2010) Evaluation of Pathogen Detection from Clinical Samples by RealTime Polymerase Chain Reaction Using a Sepsis Pathogen DNA Detection Kit. Critical Care, 14, R159. https://doi.org/10.1186/cc9234

[11] Skogberg, K., Lyytikäinen, O., Ruutu, P., Ollgren, J. and Nuorti, J.P. (2008) Increase in Bloodstream Infections in Finland, 1995-2002. Epidemiology \& Infection, 136, 108114. https://doi.org/10.1017/S0950268807008138 